\title{
A Simpler Single-Phase Single-Stage Grid- Connected PV System with Maximum Power Point Tracking Controller
}

\author{
Selim Borekci ${ }^{1}$, Ekrem Kandemir ${ }^{1}$, Ali Kircay ${ }^{2}$ \\ ${ }^{I}$ Department of Electrical \& Electronics Engineering, Akdeniz University, \\ Dumplupinar Bulv., 07058 Antalya, Turkey \\ ${ }^{2}$ Department of Electrical \& Electronics Engineering, Harran University, \\ Yenisehir Yerleskesi, 63300 Sanliurfa, Turkey \\ sborekci@akdeniz.edu.tr
}

\begin{abstract}
Generating electrical power from solar energy is very popular. There are many studies aiming at increasing the efficiency and designing simpler systems. Electrical power generated by PV cells depends on solar irradiances, ambient temperatures and electrical loads. To transfer maximum available power from PV cells to the grid, Maximum Power Point Tracker (MPPT) algorithms have been developed and implemented. In this study, a simpler single-phase single-stage grid connected system has been designed and analysed. The proposed circuit does not require complex circuitries and modulation techniques. A 175 Watt prototype system is implemented. Under different environmental conditions, the control unit forces the system to operate at the maximum available power.
\end{abstract}

Index Terms-Maximum Power Point Tracking (MPPT), PV system, single stage, solar energy.

\section{INTRODUCTION}

Demand for energy is increasing every day. Finding new energy sources are always important. Among them, renewable ones, such as wind and solar power, are popular and they are environmental friendly energy sources [1], [2]. For some locations which receive enough solar irradiance, PV panels can be preferred for generating electrical power.

The efficiency of the PV panels is around $25 \%$. When the converter and other losses are taking account, the efficiency can be down to $16 \%$ [3]. Initial investment of PV systems is high. In order to pay back itself within a shorter time period, the efficiency needs to be increased. A typical PV system consists of $\mathrm{dc} / \mathrm{dc}$ converter, voltage regulator, inverter and batteries. As a result of this, all over efficiency becomes lower. To increase the efficiency and decreases the initial capital, grid connected systems without batteries are preferred.

PV cells can generate different power depending on electrical loads at the same environmental condition. Because of that, the generation of the maximum available power is not guaranteed under all electrical loads. To transfer maximum power to the grid from PV cells, Maximum Power Point Tracking (MPPT) algorithms such

Manuscript received December 21, 2014; accepted April 12, 2015. as Hill - Climbing, Perturb \& Observe (P\&O), Fuzzy Logic Control, Incremental Conductance, Constant Voltage and Current are developed [4]. Perturb \& Observe and Incremental Conductance methods are the most common ones used in literature.

Transferring the power to the grid is completed in two stages [4]-[7]. One of stages consists of a dc-dc converter including MPPT algorithm. The second stage has a dc/ac inverter. Two stage systems are complicated and costly and additional loss occurs in each converter. Because of simplicity and low cost, single stage systems become popular [8]-[11]. In this study, a single stage system, which does not require complex circuitry and modulation techniques, is introduced. It is simpler than existing ones and also it is capable of transferring maximum available power from PV cells to the grid. $175 \mathrm{~W}$ PV system is analysed under different solar irradiance and temperature conditions to validate the proposed circuit performance.

\section{CReating Model of PV Cell AND PV PANElS}

PV cells are $\mathrm{p}-\mathrm{n}$ junction semi-conductors. In the literature, there are various types of PV cell equivalent circuit representations. Single diode equivalent circuit model is used commonly to express typical electrical characteristic of PV cells [12], [13].

A PV panel is built from connecting several PV cells in series or parallel [2]. Figure 1 shows a PV cell equivalent circuit and a PV panel with 9 cells.

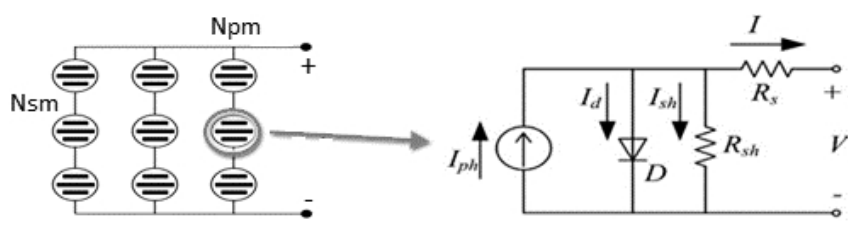

Fig. 1. A PV panel and Equivalent single diode circuit model of PV cell.

The PV load current show in Fig. 1 is defined as

$$
I=I_{p h}-I_{O}\left(\exp \left(q\left(V+R_{S} I\right) / A k T\right)-1\right)-\left(V+R_{S} I\right) / R_{S h},
$$

where A - diode quality factor $(=1.2), \mathrm{k}-$ Boltzmann constant $\left(=1.38 \times 10^{-23} \mathrm{~J} / \mathrm{K}\right), \mathrm{V}-\mathrm{PV}$ cell output voltage, $\mathrm{I}_{\mathrm{O}}-$ 
reverse-biased saturation current of the cell, Iph - PV cell photo current, $R_{S}-$ series resistance, $T$ - ambient temperature $(\mathrm{K}), \mathrm{R}_{\mathrm{sh}}-$ shunt resistance and $\mathrm{q}-$ electron charge $\left(=1.602 \times 10^{-19} \mathrm{C}\right)$.

For simplicity, $\mathrm{R}_{\mathrm{sh}}$ can be assumed as infinite. So, (1) can be simplified as

$$
I=I_{p h}-I_{o}\left(\exp \left(q\left(V+R_{S} I\right) / A k T\right)-1\right) .
$$

In order to obtain the voltage and current relationship of a PV cell, the photocurrent and reverse bias saturation currents in (2) need to be defined. PV cell photocurrent $(\mathrm{I} p h)$ in $(2)$ is

$$
I_{p h}=\left(G / G_{r e f}\right) \times I_{s c},
$$

where $\mathrm{G}$ - actual solar irradiance value, $\mathrm{G}_{\mathrm{ref}}$ - reference solar irradiance value $\left(1000 \mathrm{~W} / \mathrm{m}^{2}\right), \mathrm{I}_{\mathrm{sc}}-\mathrm{PV}$ cell short circuit current (A).

The short circuit current in (3) can be obtained from (4)

$$
I_{s c}=I_{s c r e f} \times\left(1+\alpha\left(T-T_{r e f}\right)\right),
$$

where $\mathrm{T}_{\text {ref }}$ - reference temperature $(298 \mathrm{~K}), \mathrm{I}_{\text {scref }}-\mathrm{PV}$ reference short circuit current $\left(\mathrm{G}_{\text {ref }}\right.$ and $\left.\mathrm{T}_{\text {ref }}\right), \alpha$ - temperature coefficient.

In addition to that, (5) gives the reference PV short circuit current

$$
I_{\text {scref }}=\left(I_{s c}-V_{o c} / R_{s h}\right) /\left(\exp \left(q V_{o c} / A k T_{r e f}\right)-1\right),
$$

where $\mathrm{V}_{\mathrm{oc}}$ - open circuit voltage.

Finally, the reverse bias saturation current of a cell can be obtained by (6)

$$
I_{o}=I_{\text {scref }} \times\left(T / T_{\text {ref }}\right)^{3} \times \exp \left(q E_{g} /(A k) \times\left(1 / T_{\text {ref }}-1 / T\right)\right),
$$

where $E_{g}$ - the band gap energy of the PV cell $(=1.1 \mathrm{eV})$

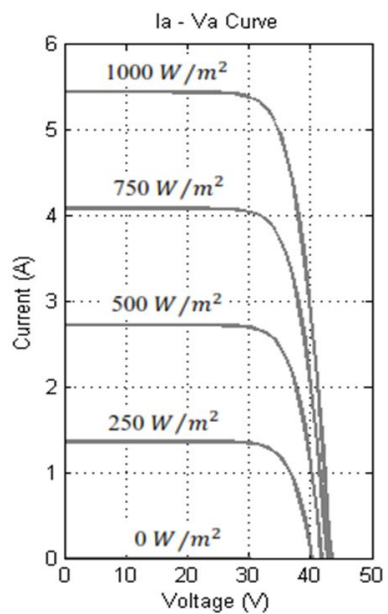

a)

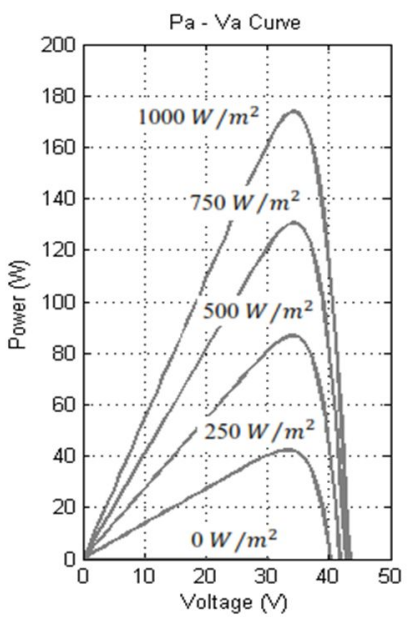

b)
Fig. 2. Current, voltage and power curves of PV panel under constant temperature and different solar irradiance condition.

After placing (3) and (6) into (2), a PV panel voltage, current and power curves can be plotted. Figure 2 shows the characteristics of a typical PV panel at constant temperature. Variation of solar irradiation alternates the PV voltage and current. Solar irradiance levels in the figure are $0 / 250 / 500 / 750 / 1000 \mathrm{~W} / \mathrm{m}^{2}$ at $25^{\circ} \mathrm{C}$. For each condition, the output power of the PV panel becomes different. The maximum power occurs at around $80 \%$ of the open circuit voltage of PV panel.

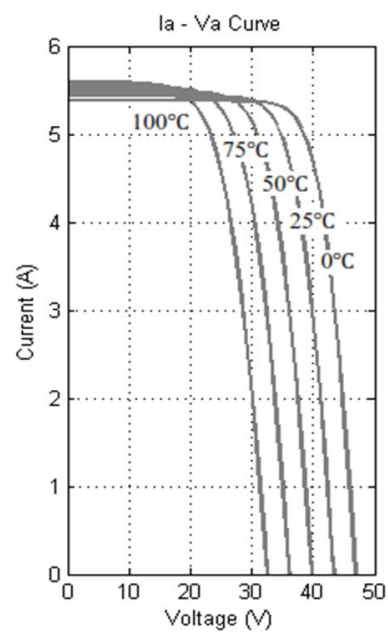

a)

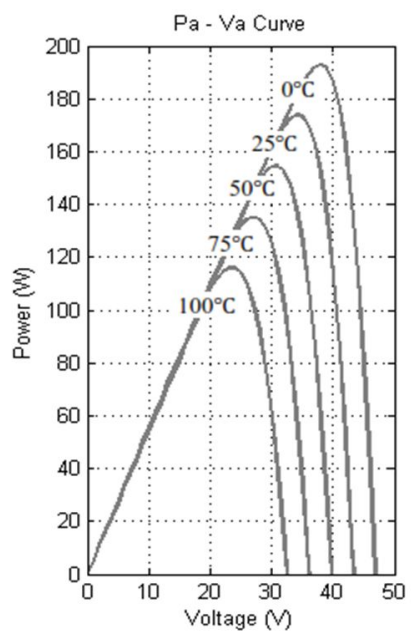

Fig. 3. Current, voltage and power curves of PV panel under constant solar irradiance and different ambient temperature condition.

In addition to solar irradiance variations, the temperature also affects the voltage-current relationship in PV cells. For different ambient temperatures, the voltage characteristic of the PV panel is shown in Fig. 3. In the figure, the ambient temperatures are $0{ }^{\circ} \mathrm{C}, 25{ }^{\circ} \mathrm{C}, 50{ }^{\circ} \mathrm{C}, 75^{\circ} \mathrm{C}$ and $100{ }^{\circ} \mathrm{C}$. Unlike previous case, the maximum available power of the PV panel can be at different voltage level.

\section{MAXIMUM POWER POINT TRACKING (MPPT) ALGORITHM FOR PV SYSTEMS}

For the same environmental condition, based on the electrical load, the operating current and voltage of PV panel have different values. Therefore, generated power by the PV panel varies. Figure 4 illustrates the voltage, current and power of PV panel for two different electrical loads. When the load resistances are equal to 3.68 and 9.53 , the output powers become $105.65 \mathrm{~W}$ and $152.53 \mathrm{~W}$ respectively.

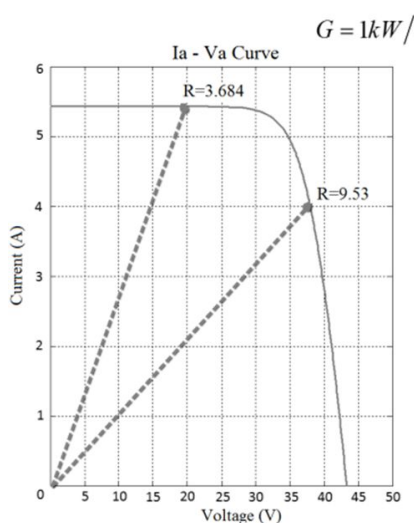

a)

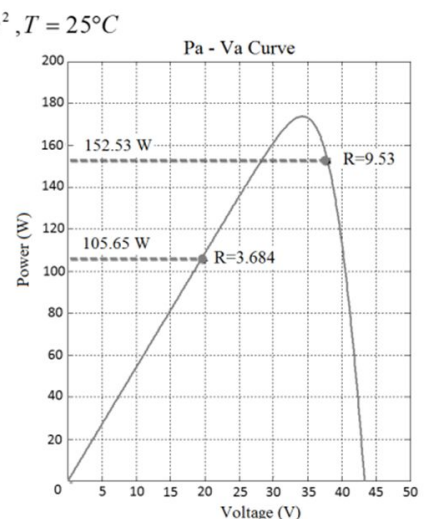

b)
Fig. 4. V - I and $\mathrm{P}-\mathrm{V}$ curves for two different electrical load values.

In both cases, output power is not the maximum available 
power. The available maximum power at the same solar irradiance and temperature is $175 \mathrm{~W}$ as shown in Fig. 5.

To utilize the PV panels at maximum performance in terms of power, additional circuits need to be designed. Then, PV panels can be run at maximum available power with any solar irradiance and temperature levels. In the literature, many MPPT algorithms have been implemented e.g. Hill - Climbing, Constant Voltage, Constant Current, Perturb \& Observe (P\&O) and Incremental Conductance.

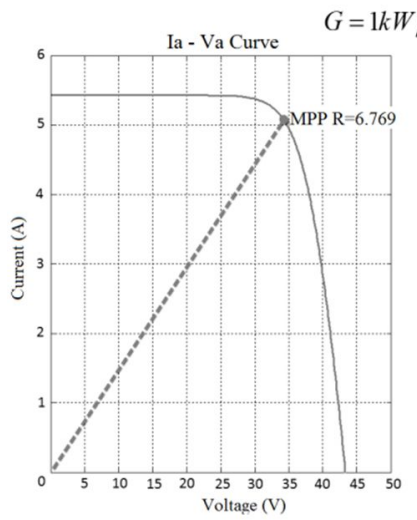

a)

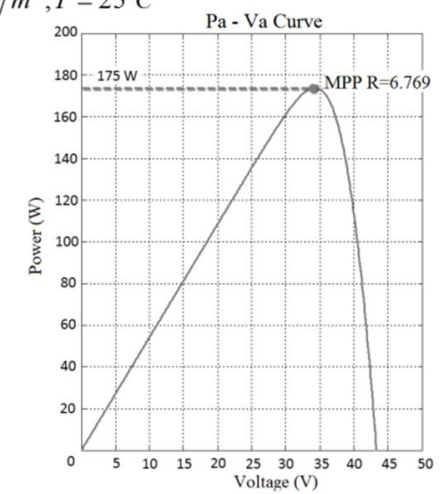

b)
Fig. 5. V - I and P-V curves for electrical load value of max. power.

In this study, P\&O MPPT algorithm method is employed. The $\mathrm{P} \& \mathrm{O}$ method measures the derivative of PV panel power $(\mathrm{dP})$ and the derivative of PV panel voltage $(\mathrm{dV})$ in order to determine the movement of the operating point. Figure 6 depicts implementation of the $\mathrm{P} \& \mathrm{O}$ algorithm for different environment conditions.

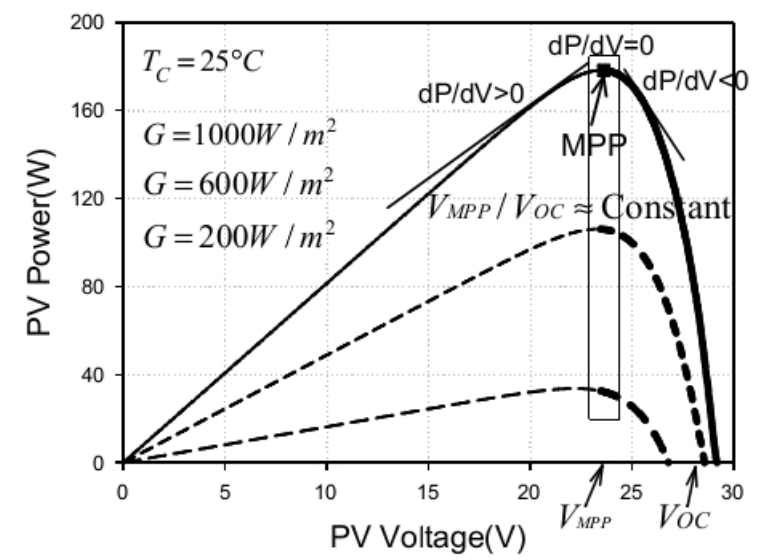

Fig. 6. $\mathrm{P} \& \mathrm{O}$ maximum power point variation diagram.

As can be seen in Fig. 6, when the sign of $(\mathrm{dP} / \mathrm{dV})$ is positive, the reference voltage of $\mathrm{PV}$ panel is increased; otherwise, the reference voltage is decreased. That is repeated, until ( $\mathrm{dP} / \mathrm{dV})$ equals to zero. The implementation of the P\&O algorithm is illustrated in Fig. 7. Detailed information can be found about the $\mathrm{P} \& \mathrm{O}$ algorithm in [14], [15].

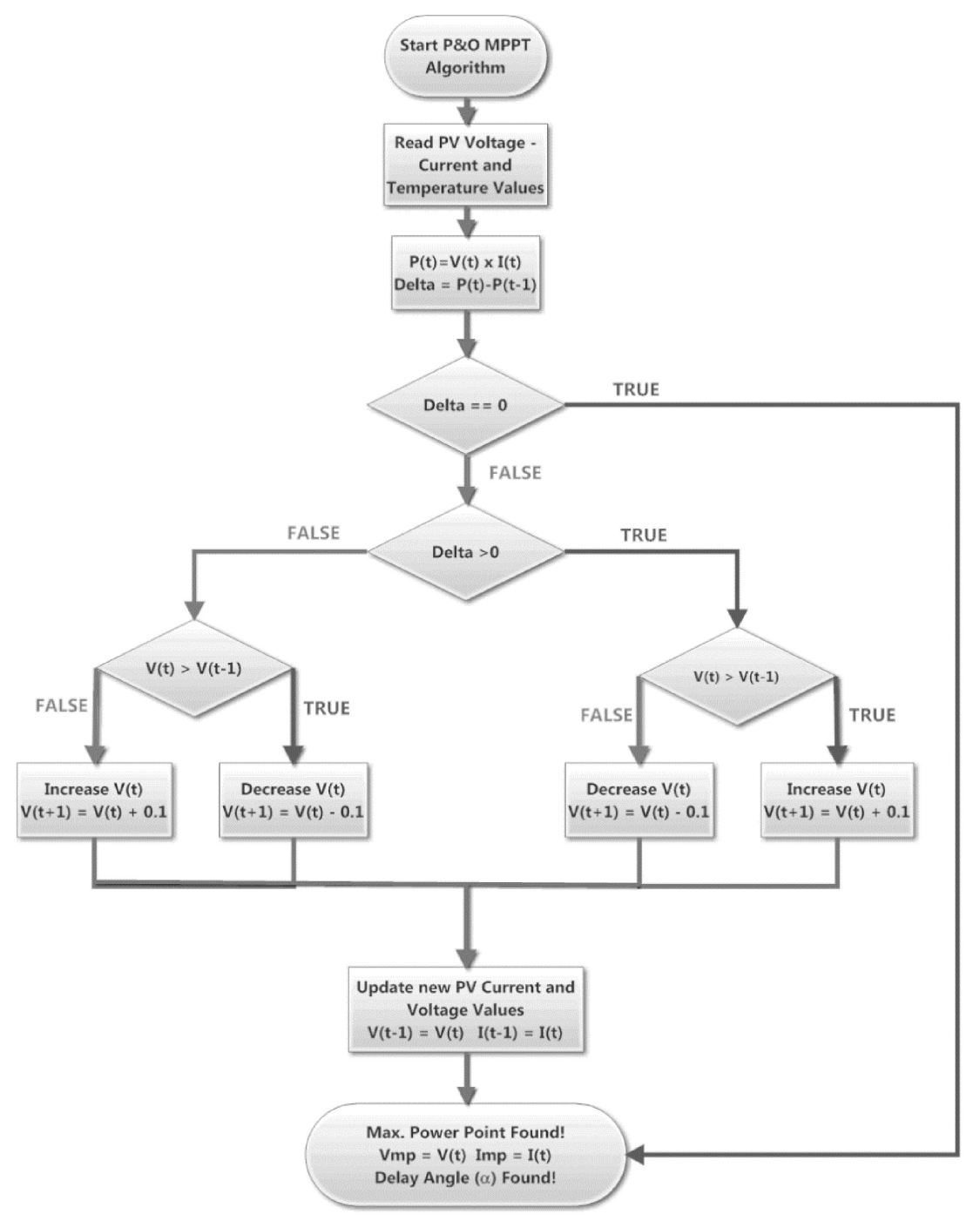

Fig. 7. P\&O maximum power point algorithm. 


\section{Controlled Single Phase Full WaVe Converter OPERATING IN INVERTER MODE}

A converter for MPPT algorithm and an inverter are designed in PV systems. Instead of using two converters, a simple controlled full wave converter can be used in rectifier or inverter mode shown in Fig. 8. In inverter mode, the delay angle of the semi-conductor devices must be higher than $90^{\circ}$. Therefore the electrical power flows from PV panel to the grid [16]. In addition to being a simple, the system does not require any modulation techniques.

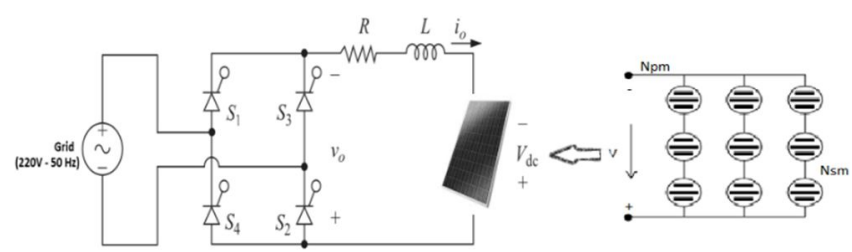

Fig. 8. Controlled full wave converter with RL - Source load.

In the controlled full wave converter system, the delay angle of the semiconductor switches called $(\alpha)$ must be also

$$
\alpha \geq \arcsin \left(V_{d c} / V_{m}\right)
$$

where $\mathrm{V}_{\mathrm{dc}}-\mathrm{DC}$ voltage source, $\mathrm{V}_{\mathrm{m}}-$ maximum voltage source of the grid.

From Fig. 8, the output voltage of the converter can be calculated from (8)

$$
V_{o}=1 / \pi \int_{\alpha}^{\pi+\alpha} V_{m} \sin (\omega t) d(\omega t)=2 V_{m} \cos (\alpha) / \pi
$$

The output current of the PV panel is

$$
I_{o}=\left(V_{o}+V_{d c}\right) / R \text {. }
$$

From (8) and (9), the transferred power to the grid can be written as

$$
P_{\text {grid }}=P_{d c}-P_{\text {loss }}=I_{o} V_{d c}-I_{o}^{2} R
$$

where $\mathrm{R}$ - the equivalent resistance of the inductor, $\mathrm{P}_{\text {loss }}-$ power losses, $\mathrm{P}_{\mathrm{dc}}-$ generated dc power.

Table I shows the operating current and voltage for the $175 \mathrm{~W}$ maximum power at the specified environmental condition given by the manufacturer $\left(\mathrm{G}=1 \mathrm{~kW} / \mathrm{m}^{2}, \mathrm{~T}=\right.$ $\left.25^{\circ} \mathrm{C}\right)$.

To meet the maximum power condition, the voltage and current defined in (8) and (9) must be the same as the current and voltage shown in Table I.

TABLE I. THE NOMINAL VOLTAGE, CURRENT AND POWER VALUES OF THE MODELLED PV PANEL IN IDEAL ENVIRONMENT CONDITION $\left(\mathrm{G}=1 \mathrm{~kW} / \mathrm{m}^{2}, \mathrm{~T}=25^{\circ} \mathrm{C}\right)$.

\begin{tabular}{|c|c|}
\hline PV Panel Voltage (V) & $35.8 \mathrm{~V}$ \\
\hline PV Panel Current (A) & $4.89 \mathrm{~A}$ \\
\hline PV Panel Power $(\mathbf{W})$ & $175 \mathrm{~W}$ \\
\hline
\end{tabular}

To ensure these conditions, the semi-conductor devices in the inverter must be controlled by a MPPT controller which determines the proper delay angle $(\alpha)$ by taking actual environment conditions into account.

Initially the proposed circuit is implemented without a MPPT controller shown in Fig. 9. A 175 W Sun Rise (SRM572175) PV panel is used. The system is analysed in MATLAB environment.

When solar irradiance is $1 \mathrm{~kW} / \mathrm{m}^{2}$ at $25^{\circ} \mathrm{C}$, the PV panel generates $175 \mathrm{~W}$ as maximum power. To meet that, the switching delay angle is calculated as $96.54^{\circ}$. Inverter bridge voltage $\left(\mathrm{V}_{\mathrm{o}}\right)$, PV panel current $\left(\mathrm{I}_{\mathrm{O}}\right)$ and output power $\left(\mathrm{P}_{\mathrm{dc}}\right)$ are illustrated in in Fig. 10.

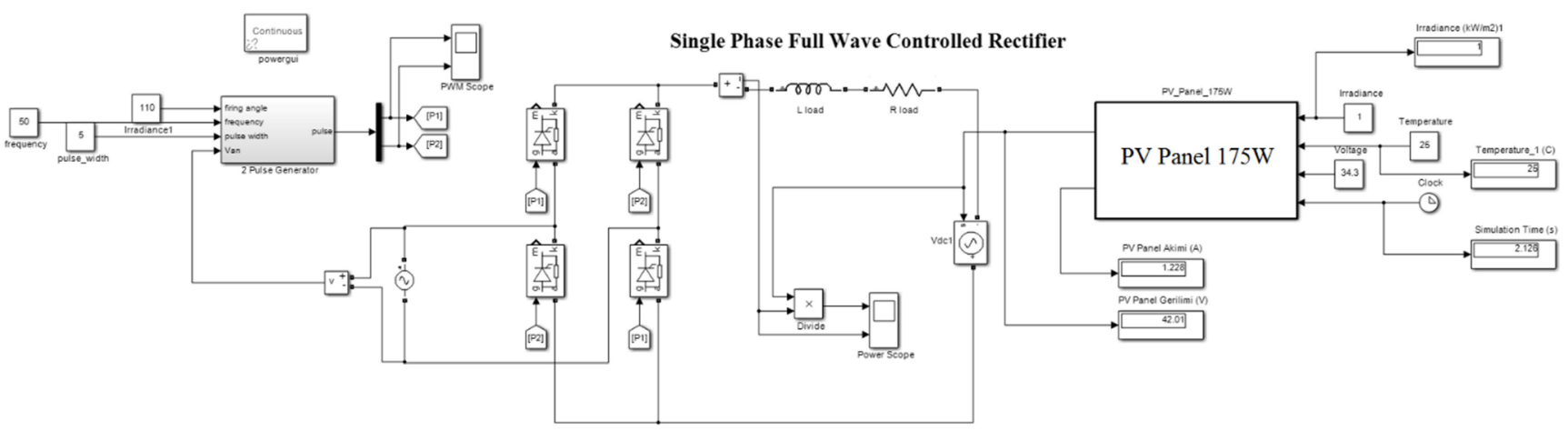

Fig. 9. Connecting $175 \mathrm{~W}$ PV panel system to grid system by controlled single phase converter in Simulink - MATLAB environment.

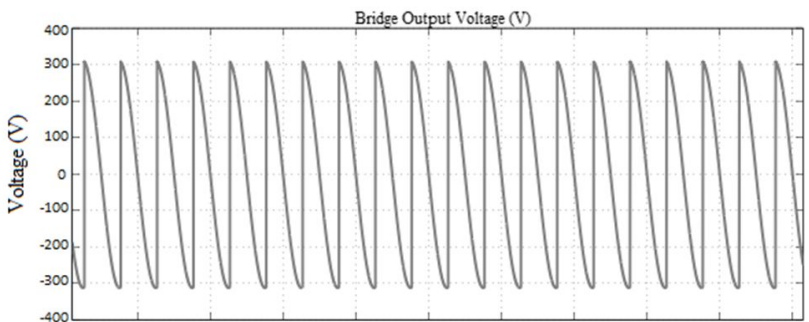

a)

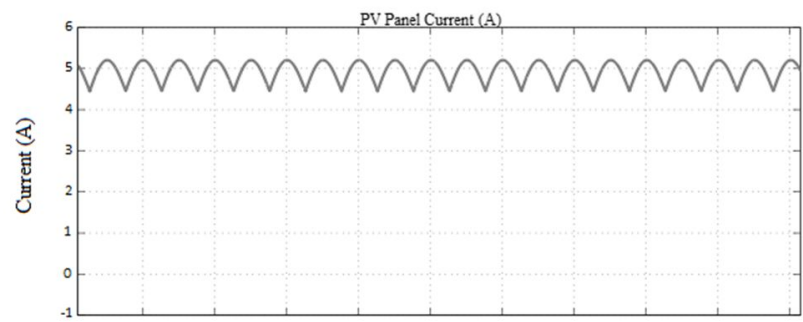

b) 


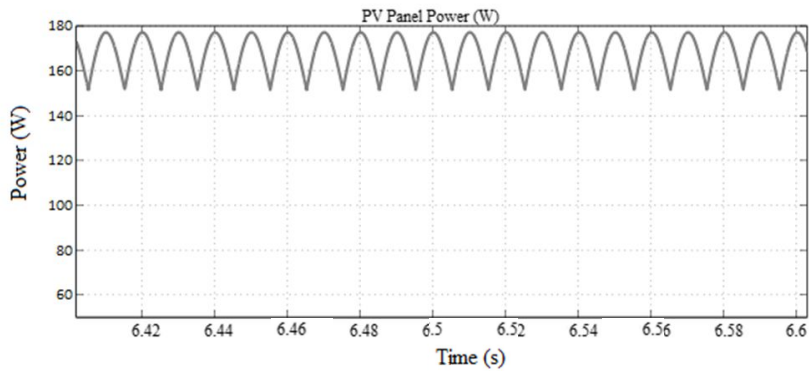

c)

Fig. 10. Output voltage $\left(V_{o}\right)-$ current $\left(I_{o}\right)$ and power $\left(P_{P V}\right)$ of the PV panel created in Simulink - MATLAB environment.

To illustrate the importance of the delay angle $(\alpha)$, two more experiments were conducted. First one was performed by adjusting the delay angle $(\alpha)$ to $110^{\circ}$ randomly at the same environmental condition as before. The output power becomes $51.6 \mathrm{~W}$. Instead of $175 \mathrm{~W}$, the system generates only $51.6 \mathrm{~W}$.

The second experiment was also performed under different environmental conditions $\left(\mathrm{G}=0.5 \mathrm{~kW} / \mathrm{m}^{2}, \mathrm{~T}=\right.$ $\left.30{ }^{\circ} \mathrm{C}\right)$. Solar irradiance is half of the previous condition and also temperature is five degree higher. From $\mathrm{P} \& \mathrm{O}$ algorithm, max available power is found out $85 \mathrm{~W}$. To meet that, the delay angle $(\alpha)$ needs to be $97.75^{\circ}$ under the new environmental condition. The experiment results are summarized in Table II. Proper delay angles for each different solar irradiance levels and temperatures must be calculated correctly by the MPPT controller. Otherwise, maximum available power cannot be generated.
TABLE II. TEST RESULTS OF THE 175W PV PANEL SYSTEM IN DIFFERENT SOLAR IRRADIANCE AND TEMPERATURE CONDITION.

\begin{tabular}{|c|c|c|c|}
\hline $\begin{array}{c}\text { Solar Irradiance } \\
\left(\mathbf{W} / \mathbf{m}^{\mathbf{2}}\right)\end{array}$ & $\begin{array}{c}\text { Temperature } \\
\left({ }^{\mathbf{}} \mathbf{C}\right)\end{array}$ & $\begin{array}{c}\text { Delay } \\
\text { Angle }(\boldsymbol{\alpha})\end{array}$ & $\begin{array}{c}\text { PV Panel } \\
\text { Power }(\mathbf{W})\end{array}$ \\
\hline 1000 & 25 & 96.541 & 173.8 \\
\hline 1000 & 25 & 110 & 51.6 \\
\hline 500 & 30 & 97.753 & 84.8 \\
\hline
\end{tabular}

\section{OPERATING THE PV SYSTEM WITH MPPT CONTROLLED SINGLE PHASE CONVERTER}

The single stage proposed system illustrated in Fig. 11 consists of three main subsystems; single phase converter (DC/AC Inverter), PV panel and MPPT controller. Environmental conditions are always in change with time.

The MPPT controller determines the maximum power value of PV panel for actual environment conditions and selects the proper delay angle $(\alpha)$.

In the proposed design, PV output voltage, current and ambient temperature are used as inputs for the MPPT controller. Then, MPPT controller determines the maximum available power.

Depend on the desired power; the controller sets the switching delay angle. After that, the semi-conductor devices in the converter are triggered by the MPPT controller.

To present the performance of the proposed design, another experiment is conducted under instantaneously changed environment. Two different environmental conditions are simulated.

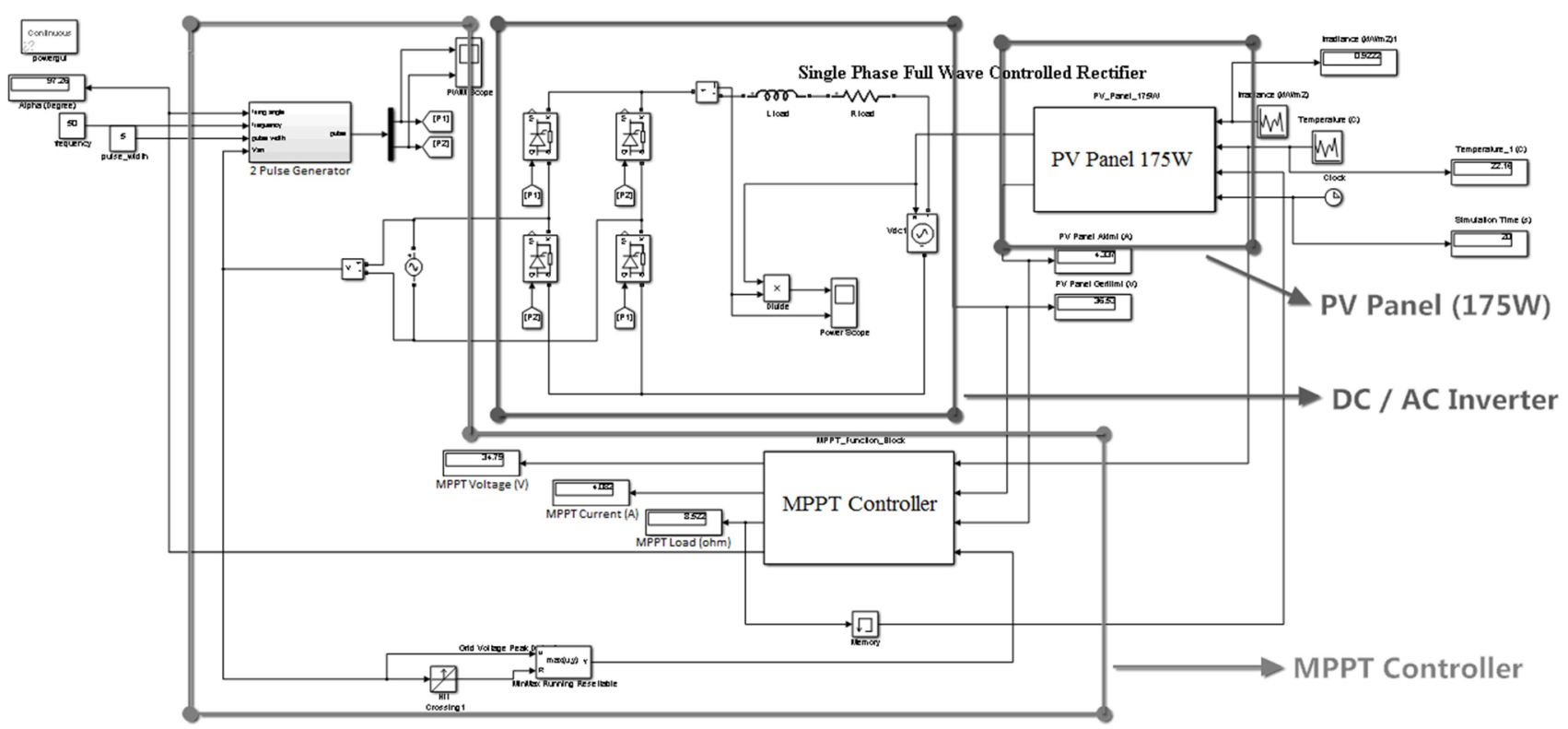

Fig. 11. Detailed system block diagram of proposed technique.

In the first one, solar irradiance is about $600 \mathrm{~W} / \mathrm{m}^{2}$ at $30.8{ }^{\circ} \mathrm{C}$ and the other is about $800 \mathrm{~W} / \mathrm{m}^{2}$ at $22.3{ }^{\circ} \mathrm{C}$. The maximum available powers for both conditions are 101.48 $\mathrm{W}(60 \%$ of max. rated power) and $141 \mathrm{~W}(80 \%$ of max. rated power) respectively. Calculated corresponding delay angles from (8) become $97.46^{\circ}$ and $97.26^{\circ}$ for the solar irradiances of $600 \mathrm{~W} / \mathrm{m}^{2}$ and $805 \mathrm{~W} / \mathrm{m}^{2}$ respectively. Results are summarized in Table III.
TABLE III. TEST RESULTS OF THE 175W PV PANEL SYSTEM IN TWO DIFFERENT ENVIRONMENT CONDITIONS.

\begin{tabular}{|c|c|c|c|c|}
\hline $\begin{array}{c}\text { Solar } \\
\text { Irradiance } \\
\left(\mathbf{W} / \mathbf{m}^{\mathbf{2}}\right)\end{array}$ & $\begin{array}{c}\text { Temp. } \\
\left({ }^{\circ} \mathbf{C}\right)\end{array}$ & $\begin{array}{c}\text { Delay Angle } \\
(\boldsymbol{\alpha})\end{array}$ & $\begin{array}{c}\text { PV Panel } \\
\text { Power } \\
(\mathbf{W})\end{array}$ & $\begin{array}{c}\text { Measured } \\
\text { PV Power } \\
(\mathbf{W})\end{array}$ \\
\hline 598.5 & 30.8 & 97.462 & 101.48 & 96 \\
\hline 804.9 & 22.32 & 97.263 & 141.98 & 136 \\
\hline
\end{tabular}




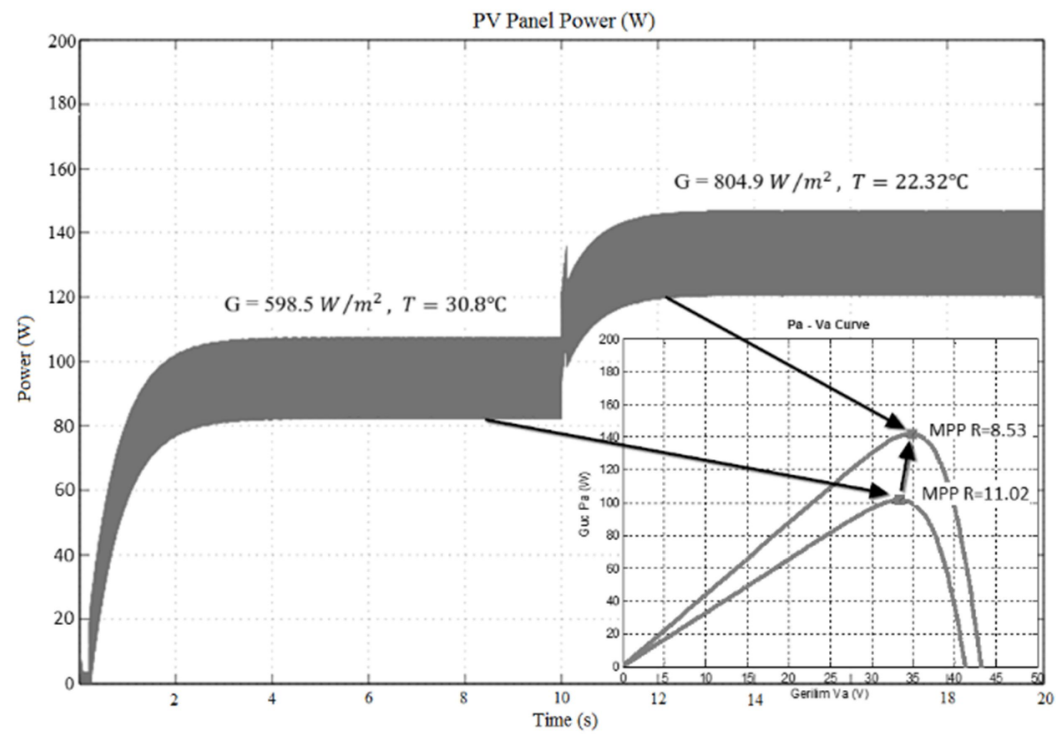

Fig. 12. Test results of the MPPT controlled PV panel system.

Instantaneous output power is plotted in Fig. 12. The average output power becomes approximately $96 \mathrm{~W}$ for the first condition and $136 \mathrm{~W}$ for the second condition. When the efficiency of the system, which is about $95 \%$, taken into account, calculated PV panel power and the output power are in harmony.

\section{CONCLUSIONS}

Generating electrical power from PV panels has become popular in recent years. In the literature, two stage complex structures are commonly used. In the proposed technique, single stage structure is used and it does not require any complex circuitry and modulation technique. A 175 Watt prototype system is designed. Under different environmental conditions, MPPT controller adjusts the delay angle successfully. In the experiment, after tuning the delay angle for the new environmental condition by the controller, the system starts generating $136 \mathrm{~W}$ instead of $96 \mathrm{~W}$.

\section{REFERENCES}

[1] A. Prodeep Kumar Yadav, S. Thirumaliah, G. Haritha, "Comparison of MPPT algorithms for DC - DC converters based PV systems", Int. Journal of Advanced Research in Electrical, Electronics and Instrumentation Engineering, pp. 18-23, 2012.

[2] J. A. Ramos Hernanz, J. J. Campayo Martin, I. Zamora Belver, J. Larranaga Lesaka, E. Zulueta Guerrero, E. Puelles Perez, "Modelling of photovoltaic module", Int. Conf. Renewable Energies and Power Quality, 2010.

[3] M. A. Green, E. Lorenzo, N. H. Post, "Solar cell efficiency tables version 16", Progress in Photovoltaics: Research and Applications, vol. 8, no. 4, pp. 377-383, 2000. [Online]. Available: http://dx.doi.org/10.1002/1099-159X(200007/08)8:4<377::AIDPIP339>3.0.CO;2-H

[4] N. L. Diaz, J. Hernandez, O. Duarte, "Fuzzy MPP method improved by a short circuit current estimator, applied to a grid-connected PV system", IEEE $12^{\text {th }}$ Workshop on Control and Modeling for Power Electronics (COMPEL), Boulder, 2010, pp. 1-6. [Online]. Available: http://dx.doi.org/10.1109/compel.2010.5562433

[5] D. Voglitsis, G. Adamidis, N. Papanikolaou, "Investigation of the control scheme of a single phase Cascade H-Bridge multilevel converter capable for grid interconnection of a PV mark along with reactive power regulation and maximum power point tracking", in IEEE $5^{\text {th }}$ Int. Symposium on Power Electronics for Distributed Generation Energy Systems (PEDG), Galway, 2014.

[6] Y. Shi, L. Liu, H. Li, Y. Xue, "A Single-phase grid-connected PV converter with minimal DC-link capacitor and low-frequency ripplefree maximum power point tracking", in IEEE Energy Conversion Congress and Exposition (ECCE), Denver, 2013, pp. 2385-2390. [Online]. Available: http://dx.doi.org/10.1109/ecce.2013.6647006

[7] Md. I. Hossain, S. A. Khan, Md. Shafiullah, M. J. Hossain, "Design and implementation of MPPT controlled grid connected photovoltaic system", IEEE Symposium on Computers \& Informatics, 2011.

[8] S. Jain, V. Agarwal, "A single-stage grid connected inverter topology for solar PV systems with maximum power point tracking", IEEE Trans. On Power Electronics, vol. 22, no. 5, pp. 1928-1940, 2007. [Online]. Available: http://dx.doi.org/10.1109/TPEL.2007.904202

[9] V. S. Lacerda, P. G. Barbosa, H. A. C. Braga, "A single-phase singlestage, high power factor grid-connected $\mathrm{PV}$ system, with maximum power point tracking", in IEEE Int. Conf. on Industrial Technology (ICIT), Vina del Mar, 2010, pp. 871-877. [Online]. Available: http://dx.doi.org/10.1109/icit.2010.5472592

[10] M. F. Kashif, S. Choi, Y. Park, Seung-Ki Sul, "Maximum power point tracking for single stage grid-connected PV system under partial shading conditions", IEEE $7^{\text {th }}$ Int. Power Electronics and Motion Control Conf., Harbin, 2012, pp. 1377-1383.

[11] C. Boonmee, Y. Kumsuwan, "Modified maximum power point tracking based-on ripple correlation control application for singlephase VSI grid-connected PV systems", in IEEE Electrical Engineering/Electronics, Computer, Telecommunications and Information Technology (ECTI-CON), Krabi, 2013, pp. 1-6. [Online]. Available: http://dx.doi.org/10.1109/ecticon.2013.6559503

[12] Kun Ding, XinGao Bian, HaiHao Liu, Tao Peng, "A MATLAB Simulink based PV module model and its application under conditions of non-uniform irradiance", IEEE Trans. on Energy Conversion, 2012.

[13] F. M. Gonzalez - Longatt, "Model of photovoltaic module in Matlab", (II CIBELEC 2005), 2005.

[14] Br. Khiari, A. Sellami, R. Andoulsi, "MPPT control of photovoltaic pumping system based on discrete sliding mode", Int. Renewable Energy Congress, 2010, pp. 66-72.

[15] M. A. Gomes de Brito, L. Galotto, L. P. Sampaio, G. A. Melo, C. A. Canesin, "Evaluation of the main MPPT techniques for photovoltaic applicaitons", IEEE Trans. Industrial Electronics, vol. 60, pp. 1156-1167, 2013. [Online]. Available: http://dx.doi.org/10.1109/TIE.2012.2198036

[16] D. W. Hart, Power Electronics. McGraw - Hill, 2010. 